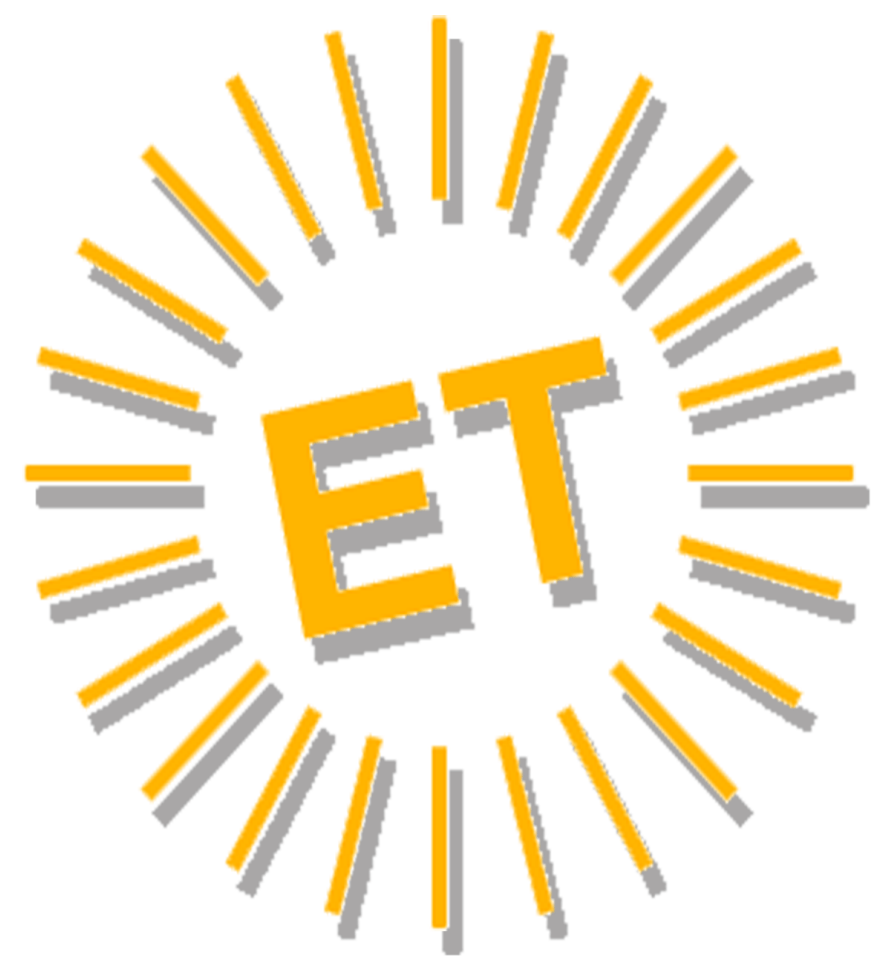




\section{Editorial Team}

\section{Editor in Chief}

Alfonso Vargas-Sánchez, University of Huelva, Spain

\section{Associate Editor}

Mirko Perano, Reald University College, Albania

\section{Books Review Editor}

Brendan Paddison, York St. John University, United Kingdom

\section{Secretariat}

Elena García de Soto, University of Huelva, Spain

Cinta Borrero-Domínguez, University of Seville, Spain

\section{Style reviewer and text editor}

Anestis Fotiadis, Zayed University, United Arab Emirates

\section{Editorial Board}

José Manuel Alcaraz, Murdoch University, Australia Mario Castellanos-Verdugo, University of Seville, Spain José Antonio Fraiz-Brea, University of Vigo, Spain José Manuel Hernández-Mogollón, University of Extremadura, Spain

Tzung-Chen Huan, National Chiayi University, Taiwan, Province of China

Shaul Krakover, Ben Gurion University, Israel Jean Pierre Levy-Mangin, University of Quebec, Canada Tomás López-Guzmán, University of Córdoba, Spain Yasuo Ohe, Chiba University, Japón

María de los Ángeles Plaza-Mejía, University of Huelva, Spain Nuria Porras-Bueno, University of Huelva, Spain João Albino Silva, Algarve University, Portugal

\section{Advisory Board (Spanish Members)}

Juan Manuel Berbel-Pineda, Pablo de Olavide University, Spain César Camisón-Zornoza, Uniersity of Valencia, Spain Enrique Claver-Cortés, University of Alicante, Spain María Teresa Fernández-Alles, University of Cádiz, Spain José Luis Galán-González, University of Seville, Spain Félix Grande-Torraleja, University of Jaén, Spain

Antonio Leal-Millán, University of Seville, Spain Inmaculada Martín-Rojo, University of Málaga, Spain Antonio Manuel Martínez-López, University of Huelva, Spain Francisco José Martínez-López, University of Huelva, Spain Pablo A. Muñoz-Gallego, University of Salamanca, Spain
Francisco Riquel-Ligero, University of Huelva, Spain José Miguel Rodríguez-Antón, Autonomous University of Madrid, Spain

Sandra Sanchez-Cañizares, University of Cordoba, Spain Josep Francesc Valls-Giménez, ESADE, Spain

\section{Advisory Board (Other European Members)}

Tindara Abbate, University of Messina, Italy Paulo Aguas, University of Algarve, Portugal Carlos Costa, Aveiro University, Portugal Dianne Dredge, Aalborg University, Denmark Salvatore Esposito de Falco, University of Rome "La Sapienza", Italy

Sheila Flanagan, Dublín Institute of Technology, Ireland Tania Gorcheva, Tsenov Academy of Economics, Bulgaria Tadeja Jere Jakulin, University of Primorska, Slovenia Metin Kozak, Mugla University, Turkey Álvaro Matias, Lusiada University, Portugal Alfonso Morvillo, National Research Council, Italy Alexandru Nedelea, Stefan cel Mare University of Suceava, Romania Claudio Nigro, University of Foggia, Italy Angelo Presenza, University "G. D'Annunzio" of Chieti-Pescara, Italy

Kanes Rajah, Royal Agricultural University, United Kingdom

\section{Advisory Board (Members from the rest of the world)}

John Allee, American University of Sharjah, United Arab Emirates

Nestor Pedro Braidot, National University of La Plata, Argentina

Roberto Elias Canese, Columbia University, Rector, Paraguay

Luca Casali, Queensland University of Technology, Australia Nimit Chowdhary, Indian Institute of Tourism and Travel Management, India

Steven Chung-chi Wu, National Pingtung University of Science and Technology, Taiwán

Dianne Dredge, Southern Cross University, Australia Daniel Fesenmaier, Temple University, United States

Babu George, Alaska Pacific University, United States Dogan Gursoy, Washington State University, United States Jafar Jafari, University of Wisconsin-Stout, United States Sanggun Lee, Pai Chai University, Korea Republic of Albert Yeh Shangpao, I-SHOU University, Taiwán Pauline Sheldon, University of Hawaii, United States Germán A. Sierra-Anaya, University of Cartagena de Indias, Rector, Colombia Xiaohua Yang, University of San Francisco, United States 


\title{
SUFFICIENCY AND INSUFFICIENCY OF HOTEL FACILITIES AND SERVICES FOR GUESTS WITH SPECIAL NEEDS: THE CASES OF PORTUGAL AND CYPRUS
}

\author{
Sotiroula Liasidou \\ Cyprus University of Technology (Cyprus) \\ sotiroula.liasidou@cut.ac.cy \\ Jorge Umbelino \\ Estoril Higher Institute for Tourism \& Hotel Studies - CiTUR (Portugal) \\ jorge.umbelino@eshte.pt \\ Cláudia Viegas \\ Polytechnic Institute of Lisbon - CiTUR (Portugal) \\ claudia.viegas@estesl.ipl.pt

\section{ABSTRACT} \\ Adequate facilities and appropriate customer service in the hotel industry \\ are needed to cater the increasing numbers of people with special needs, \\ including within the senior cohort. This paper purpose is to assess and \\ compare the cases of Cyprus and Portugal - countries that are highly \\ dependent on the tourism industry - and to identify whether their hotels \\ have the necessary facilities and employees are well equipped to support \\ guests with special needs. The results reveal that both Portuguese and \\ Cypriot hotels regard their facilities as adequate for people with physical \\ disabilities but exclude guests with other types of disabilities. Furthermore, \\ employees are not well prepared to provide services to this cohort of the \\ market. This failure to develop the necessary structures has implications \\ for these countries' competitiveness in terms of becoming accessible and \\ disabled-friendly destinations.
}


KEYWORDS

Special needs; Customer service; Hotel industry; Cyprus; Portugal.

ECONLIT KEYS

I14; 115

\section{INTRODUCTION}

For most people today, travelling is easier than ever before. However, this is not true of the segment of people with disabilities (hereafter PwD) and other special needs. The population of PwD worldwide is reaching one billion (Chernaya et al. 2019) and in the European Union (EU) alone, more than 100 million persons have disabilities (European Disability Forum 2019). Doubts have been expressed about these numbers, but it is important to recognise that in tourism, the so-called disability market includes much more than 'formally' disabled guests, namely seniors, who often have to handle not only one but several impairments, which represent huge constrains in their lives (Huber, Milne \& Fyde, 2018; Ambrose, 2016; Ancell \& Graham, 2016; WHO, 2019; Bowtell, 2015). The number of people involved in this market increases once one considers the people accompanying PwD during their travels, for instance family members and friends who are also their caregivers (Lehto et al., 2018).

Over the last decade, studies on accessible tourism have become increasingly important (Table 1). This is attributable to the continuing increase in people with special needs (hereafter PwSN) travelling for the purpose of tourism and reflects the growing need for research extending beyond interpersonal dynamics to the provision of more personalised customer service (Darcy, 2019; UNWTO, 2019; Lyu, 2017; Darcy, Cameron \& Pegg, 2010; Bi et al., 2007; Daniels, Rodgers \& Wiggins, 2005). Many researchers have addressed accessible tourism by discussing issues pertaining to tourism and PwD and People with Special Needs (hereafter PwSN), not only as part of the social justice of inclusion but also as an economic opportunity (Casaccia, Garofalo \& Marchesano, 2017). Gillovic, McIntosh, Darcy \& Cockburn-Wootten (2018) research put forth on the inconsistency in language used by tourism scholars and provide a misunderstanding on the parameters that enable the provision of services and facilities to PwD. Future developments of accessible tourism are dealt with a unified process of development through a concentration on PwD rights as part of the inclusion (Michopoulou, Darcy, Ambrose \& Buhalis, 2015). 


\begin{tabular}{|c|c|c|}
\hline Author(s) & Year & Level of context / theme of discussion \\
\hline $\begin{array}{l}\text { Kalargyrou, } \\
\text { Trivellas \& Sigala }\end{array}$ & 2020 & $\begin{array}{l}\text { Guests' stereotyping and quality } \\
\text { evaluations of service delivered by employees with } \\
\text { disabilities }\end{array}$ \\
\hline Darcy & 2019 & $\begin{array}{l}\text { Leisure with impact: research, human rights, and } \\
\text { advocacy in a reflective review of a research career }\end{array}$ \\
\hline Pagan & 2019 & $\begin{array}{l}\text { How important are holiday trips in preventing } \\
\text { loneliness? Evidence for people without and with self- } \\
\text { reported moderate and severe disabilities }\end{array}$ \\
\hline Porto et al. & 2019 & $\begin{array}{l}\text { Accessible tourism for destination competitiveness } \\
\text { and comparison case studies: Oceania and South } \\
\text { America }\end{array}$ \\
\hline $\begin{array}{l}\text { Devile \& } \\
\text { Kastenholz }\end{array}$ & 2018 & $\begin{array}{l}\text { Accessible tourism experiences: the voices of people } \\
\text { with visual disabilities }\end{array}$ \\
\hline $\begin{array}{l}\text { McKercher \& } \\
\text { Darcy }\end{array}$ & 2018 & Barriers to travel for people with disabilities \\
\hline Lehto et al. & 2018 & $\begin{array}{l}\text { Shared tourism experiences of individuals with } \\
\text { disabilities and their caregivers }\end{array}$ \\
\hline $\begin{array}{l}\text { Tchetchik, } \\
\text { Eichhorn \& Biran }\end{array}$ & 2018 & $\begin{array}{l}\text { 'Not on my vacation': service encounters between } \\
\text { able-bodied and disabled consumers - the case of } \\
\text { high-contact service }\end{array}$ \\
\hline $\begin{array}{l}\text { Casaccia, Garofalo } \\
\& \text { Marchesano }\end{array}$ & 2017 & $\begin{array}{l}\text { Tourism and disability in Italy: limitations and } \\
\text { opportunities }\end{array}$ \\
\hline Ancell \& Graham & 2016 & $\begin{array}{l}\text { A framework for evaluating the European airline costs } \\
\text { of disabled persons and persons with reduced } \\
\text { mobility }\end{array}$ \\
\hline $\begin{array}{l}\text { Michopoulou, } \\
\text { Darcy, Ambrose \& } \\
\text { Buhalis }\end{array}$ & 2015 & Accessible tourism futures \\
\hline $\begin{array}{l}\text { Vila, Darcy \& } \\
\text { González }\end{array}$ & 2015 & $\begin{array}{l}\text { Competing for the disability tourism market: a } \\
\text { comparative exploration of the factors behind } \\
\text { accessible tourism competitiveness in Spain and } \\
\text { Australia }\end{array}$ \\
\hline Chang \& Chen & 2012 & $\begin{array}{l}\text { Meeting the needs of disabled air passengers: factors } \\
\text { that facilitate help from airlines and airports }\end{array}$ \\
\hline Chang \& Chen(a) & 2012 & $\begin{array}{l}\text { Overseas travel choice for persons with reduced } \\
\text { mobility }\end{array}$ \\
\hline $\begin{array}{l}\text { Poria, Reichel \& } \\
\text { Brandt }\end{array}$ & 2011 & $\begin{array}{l}\text { Dimensions of hotel experience of people with } \\
\text { disabilities }\end{array}$ \\
\hline $\begin{array}{l}\text { Bizjak, Knezevic \& } \\
\text { Cvetreznic }\end{array}$ & 2011 & $\begin{array}{l}\text { Attitude changes towards guests with disabilities: } \\
\text { reflections from tourism students }\end{array}$ \\
\hline Var et al. & 2011 & The travel patterns of physically disabled people \\
\hline $\begin{array}{l}\text { Darcy, Cameron \& } \\
\text { Pegg }\end{array}$ & 2010 & $\begin{array}{l}\text { Towards strategic intent: perceptions of disability } \\
\text { service provision amongst hotel accommodation } \\
\text { managers }\end{array}$ \\
\hline
\end{tabular}




\begin{tabular}{|l|l|l|}
\hline Grady \& Ohlin & 2009 & $\begin{array}{l}\text { Equal access to hospitality services for guests with } \\
\text { mobility impairments }\end{array}$ \\
\hline $\begin{array}{l}\text { Burns, Paterson \& } \\
\text { Watson }\end{array}$ & 2009 & $\begin{array}{l}\text { Disabled people's experiences of countryside leisure } \\
\text { services }\end{array}$ \\
\hline $\begin{array}{l}\text { Packer, McKercher } \\
\text { \& Mathew }\end{array}$ & 2007 & $\begin{array}{l}\text { Understanding the complex interplay between } \\
\text { tourism, disability and environmental contexts }\end{array}$ \\
\hline $\begin{array}{l}\text { Tantawy, Kim \& } \\
\text { Pyo }\end{array}$ & 2005 & Evaluation of hotels to accommodate disabled visitors \\
\hline $\begin{array}{l}\text { Shaw \& Coles } \\
\begin{array}{l}\text { Yau, McKercher \& } \\
\text { Packer }\end{array}\end{array}$ & 2004 & $\begin{array}{l}\text { Disability, holiday making and the tourism industry in } \\
\text { the UK: a preliminary survey }\end{array}$ \\
\hline Raya \& Ryderb & 2003 & $\begin{array}{l}\text { Traveling with a disability: more than an access issue } \\
\text { travel needs and motivations of the mobility-disabled }\end{array}$ \\
\hline Burnett \& Baker & 2001 & $\begin{array}{l}\text { Assessing the travel-related behaviours of the } \\
\text { mobility-disabled consumer }\end{array}$ \\
\hline
\end{tabular}

Table 1: Previous studies on accessible tourism. Source: Authors.

In the case of tourism, Murray and Sproats (1990) have contributed to the literature with the article 'The disabled traveller: tourism and disability in Australia', identifying three preventive factors for travelling: economic, physical and attitudinal. These three parameters are applicable even today in relation to PwD/PwSN and tourism. Indeed, even if the economic barrier is overcome, the main problems of PwD/PwSN remain related to physical movement and the way other people confront and interact with them (Tantawy et al., 2005). In terms of travel decisions, considerable concern pertains to the facilities offered at the destination in relation to PwD/PwSN, this being the primary determinant of their final choice (Darcy, 2010). In the same vein, Shaw and Coles (2004) have stated that destination accessibility starts from information management, this playing an important role in disabled travel and a key factor in PwD's decision making (Blichfeldt \& Nicolaisen, 2011; Buhalis \& Michopoulou, 2011; Darcy, 2010; Burns, Paterson \& Watson, 2009). Additionally, Michopoulou et al. (2015) emphasised on the issue of inclusivity for destination sustainable development as part of the 'UN Agenda 2030'.

The purpose of this study is to address the issue of accessibility in hotels by considering the cases of Cyprus and Portugal. This study will attempt to identify whether hotels are providing accessible facilities and services, so that the two countries can be compared. Additionally, to provide an understanding on the 
characteristics of the market (PwD/GwSN). Finally, to understand the efficiency of the human resources: skills, procedures and training actions considering servicing PwD/GwSN. It should be emphasized that both countries' economies are highly dependent on tourism and the inclusion of disabled services in order that they can be considered as 'accessible destinations', with great emphasis placed on the hotel industry, will bring many economic and social benefits.

\section{LITERATURE REVIEW}

\section{1) ADDRESSING DISABILITY THEORY IN RELATION TO TOURISM}

Disability theory is rather limited in the tourism concept, even if great improvements have been made in the industry to include and satisfy the demands of impaired or disabled travellers (Michopoulou et al., 2015; Huber, Milne \& Fyde, 2018; Caro, Waal \& Buhalis, 2012; Koo Lee et al., 2012; Shaw \& Coles, 2004). The dimension of the senior market for tourism and the evidence that this population reflects the disability concept as well as the inherent special needs it demands have stimulated a very interesting economic discussion (Ambrose, 2016, 2012; Bizjak, Knezevic \& Cvetreznic, 2011). According to Scope (2021), the term 'disablism' can be defined as 'discriminatory, oppressive or abusive behaviour arising from the belief that PWD are inferior to others'. Essentially, social access is prohibited because of impediments caused by society. The 2006 UN Convention states that the concept of disability is more closely related to social misunderstanding/misbehaviour concerning our collective responsibility than to personal impairments. Shakespeare and Watson (2002:5) make a differentiation in terms of 'the impairment that people have, and the oppression they experience'. PwD argue in terms of social acceptance (for instance, tourism represents an important part of humans' lives), thus the exclusion of any group of people is unacceptable (Hughes \& Paterson, 1997; Devıne, 2004; Liasidou, Umbelino \& Amorim, 2019; Tatic, 2015).

Kastenholz, Eusébio \& Figueiredo (2015) have discussed the concepts of social inclusion and exclusion of people with disabilities in the context of tourism. In Europe, there is a representative body of persons with physical disabilities - 'The Representative State Platform for Persons with Physical Disabilities' (PREDIF) - which 
attempts to ensure that 'accessibility is integrated in all policies' (UNWTO 2015). In particular, the President of PREDIF, Francisco Sardón, has pertinently stated that 'accessibility is synonymous with tourism quality' and that 'all persons, with or without disability benefit from it' (UNWTO, 2015). Admittedly, many researchers have emphasised the fact that people with disabilities have the right to travel and destinations should respond adequately to satisfy their needs and enhance their experiences (Devile \& Kastenholz, 2018; Michopoulou et al., 2015; Smith, Amorim \& Umbelino, 2013). Burns, Paterson and Watson (2009) have argued that the PwD market is hugely diverse, so special attention should be given to understanding specific needs.

In tourism development, accessibility is a new concept in the tourism vocabulary and is compatible with sustainability, destination image and innovation (Benjamin, Bottone \& Lee, 2021; Caro, Waal \& Buhalis, 2012). However, the issue is that inclusion through a policy enables and safeguards the status of PwD in society (Kastenholz, Eusébio \& Figueiredo, 2015; Scott, 2011). It is also imperative, firstly from a human perspective and secondly as part of corporate responsibility, not to discriminate against disabled customers and to provide all the necessary equipment to make their mobility easier (Scott, 2011; Kalargyrou, Trivellas \& Sigala, 2020). Initially, social tourism was defined by Hunzicker (1951, p.1, cited in Minnaert, Maitland \& Miller, 2011, p. 404) as 'the relationships and phenomena in the field of tourism resulting from participation in travel by economically weak or otherwise disadvantaged elements in society'. This connotes the idea that tourism is an activity that should not prevent anyone from participating, thus it is imperative to identify how either social or economic barriers may be overcome (Minnaert, 2012; McCabe, Minnaert \& Diekmann, 2011; Minnaert, Maitland \& Miller, 2011; Minnaert, Maitland \& Miller, 2009; Shaw \& Coles, 2004). Great emphasis is given in the wider context of tourism that the prohibition of service delivery to a disabled customer constitutes a form of discrimination (Kalargyrou, Trivellas \& Sigala, 2020; Ozturk, Yayli \& Yesiltas, 2008). This focus is relevant and absolutely needed, but changing the point of view, it does not highlight the economic expectations that the PwD market can bring. The next part considers accessibility to hotels' facilities and services.

\section{2) ESTABLISHING ACCESSIBLE HOTELS: FACILITIES AND SERVICES}


When one arrives at a hotel, the key question relates to the comfort of the accommodation, both in terms of physical facilities and human services (Naniopoulos, Tsalis \& Nalmpantis, 2016; Navarro, Garzón \& Roig-Tierno, 2015; Ambrose, 2012). Hotel facilities for Guests with Disabilities (hereafter GwD) should include all supporting physical equipment that is needed to ensure that they will experience the hotel seamlessly (Tchetchik, Eichhorn \& Biran, 2018). Essential are the provision of ramps, parking areas, specially adjusted rooms and bathrooms as well as special hearing aids and visual aids for blind and deaf people, respectively, along with other facilities adjusted to the needs of people with mental disorders (Tantawy et al., 2005). Therefore, hotels without the necessary facilities to serve guests with special needs (hereafter GwSN), such as mobility impairments and thus needing a wheelchair (for instance, hotels in historical buildings), can be included in this segment, by opening up and adjusting their services to cater to people with other impairments, like those related to vision, hearing and cognition (Landby, 2019; Lehto et al., 2018).

In the case of hotel services, the most important component is employees who have direct contact with guests and assume a special responsibility to ensure that they are satisfied, sometimes requiring that they pre-empt eventual physical constraints (SOCYTEC, 2007).

Therefore, they must understand how to satisfy their guests' needs and to deliver the requested services (Wang \& Wilcox, 2006; Swansson, 2005; Zhang \& Wu, 2004; Fernández Alles, 2007; Storey, 1995). In the human resources literature, guests' interactions with staff have been described as 'moments of truth' (Carlzon, 1987, p. 10). Indeed, it is believed that:

through HRM (Human Resources Management) Best Practice, organizations will see enhanced commitment from employees leading to improved organizational performance, higher levels of service quality and ultimately increased productivity and profitability.

(Nickson, 2007)

Another example of good practice that can be applied in hotels is an initiative called the 'Disability Smart Award', led by the Disability Forum, a not-for-profit member organisation in the UK. In particular, 
Business Disability Forum believes inclusive and accessible customer service should be standard practice and that every workplace should be a great place to

work. The Disability-Smart Awards aims to showcase and celebrate the most innovative and inclusive practice among employers and service providers.

(Disability Forum, 2018)

Especially when catering to PwD, 'moments of truth' along with good practices become more important, given the special characteristics of this market.

According to the Disabled World website (2016), apart from the physical problems faced by disabled guests in hotels, hotel employees are not well equipped and trained to cater to this cohort of travellers. Serving Guests with Disabilities (hereafter PwD GwD) in hotels is particularly demanding and appropriate training is needed. Employees should be trained adequately and develop certain skills to be able to provide all the necessary services to a clientele that is composed of diverse types of people (Darcy \& Pegg, 2011; Var et al., 2011). Each hotel must develop an internal culture, defined as 'the way we do things around here' (Deal \& Kennedy, 1982, p. 4), based on written and verbal communication. Additionally, mentoring, and coaching schemes are vital with the provision of guidance by experienced employees (Yang, Guo, Wang \& Li, 2019) to ensure that GwD are served adequately.

Through a more 'disabled-friendly culture', hotels need to deeply engage not only with ethical considerations and non-discriminatory principles in terms of providing services to GwD (Darcy \& Pegg, 2011) but also to employ PwD (Gröschl, 2007). In addition, according to the European Commission (2004), when these groups within the market receive adequate services, they feel more committed and loyal to the organisations providing them. On the one hand, there is a social obligation to the providers of leisure products to ensure that all humans enjoy the same level of access. On the other hand, the provision of accessible facilities to cater to the needs of GwD is promising given its growth, which can be viewed as an economic opportunity both to tourism suppliers and destinations. The next part considers the cases of Portugal and Cyprus in relation to accessibility in the tourism field.

\section{3) ACCESSIBLE TOURISM: THE REALITIES OF CYPRUS AND PORTUGAL}


In both countries, tourism is a very important sector in economic and social terms. The main figures from the World Travel and Tourism Council study 'Economic Impact 2019' are shown in Table 2 (WTTC, 2020). There is no doubt regarding the importance of the sector, no matter whether the analysis is focused on the national level or compares other places within the EU or the world. In the European context, Cyprus and Portugal are both EU member states and thus subject to the European Committee for Standardization (ECS) with CEN/TC 329 Tourism Services, of which the provision of Accessible Tourism Services represents an important part (European Committee for Standardization, ECS 2019). At the international level, the International Organization for Standardization (ISO), which is an independent and non-governmental international organisation, includes the ISO/TC 228 'Tourism and related services', with special reference to ISO/TC 228/WG 14, which provide guidelines on accessible tourism (ISO 2019). Additionally, both countries are committed to Regulation (EC) No. 1107/2006 of the European Parliament (2006) and of the Council of 5 July 2006 concerning the rights of disabled persons and persons with reduced mobility when travelling by air. A development in the EU is the provision of the 'European Blue Badge' for accessing disable parking places (European Commission 2019).

\begin{tabular}{|l|c|c|c|c|}
\hline & World & EU & Cyprus & Portugal \\
\hline Total contribution to GDP & 10.3 & 9.1 & 13.8 & 16.5 \\
\hline Total contribution to employment & 10.0 & 9.7 & 13.2 & 18.6 \\
\hline
\end{tabular}

\subsection{1) CYPRUS}

The 'Tourism Strategic Plan 2017-2030' sets the foundation to diversify the country's tourism product through concentrating on 'special interest activities' (Ministry of Commerce Industry and Tourism -MCIT-, 2017). The regulatory framework at the national level of Cyprus is not specific to tourism but rather based on the Persons with Disabilities Laws 2000-2007 (European Commission, 2014; Mavrou \& Liasidou, 2012). The official tourism website (https://www.visitcyprus.com/index.php/en/) provides information regarding accessibility services through a link to 'Accessible Cyprus' (https://www.visitcyprus.com/index.php/en/practical-info/accessible). Information from the Cyprus Confederation of Organisations of the Disabled (CCOD) 
(http://www.kysoa.org.cy/kysoa/page.php?pagelD=3) and the Cyprus Paraplegic Association are also presented to potential visitors so that they can obtain precise information (http://opak.org.cy/). The hospitality industry provides $30 \%$ (the highest share) of the island's total active employment (Ernst and Young, 2013, p. 54). In the case of this industry, the Hotel Regulation (Republic of Cyprus, 2014) states that hotels are obliged to ensure that $5 \%$ of their room capacity is accessible to those with disabilities. Nevertheless, not all hotels offer disabled facilities and even where they claim to do so, their facilities are often insufficient and do not fulfil the requirements of PwD.

\subsection{2) PORTUGAL}

In Portugal, the Regulation on Accessibility has been extended to sectors other than tourism, namely: Law 46/2006, 28 August, about non-discrimination based on disabilities; Decree-Law 163/2006, 8 August, about access to public spaces; and Decree-Law 74/2007, 27 March, about guide dogs' access to public spaces. During the last few years, the National Authority for Tourism, Turismo de Portugal (TP), has provided a large set of initiatives on the topic, starting from the 'All for All' Programme [financial support for Destination Management Organisations (DMO) and businesses], passing through the sharing of 'Good Practices Recommendations' on its website (Manuals on Accessibility for Hotels and on Outdoors Activities) as well as including the support of the website and app platform 'Tur4All' (Accessibility Information) and the Portuguese Standard NP 4523 (Accessibility in Hotels). Information to all these programmes is available on the TP's website (www.turismodeportugal.pt).

The agency that manages ten airports in Portugal (ANA) also has a very interesting programme to assist passengers with any kinds of impairments - the 'My Way Programme'1 - and as symbolic evidence, in 2019 the country was recognised by the WTO as an 'Accessible Tourism Destination' in the first edition of this prize (ENAT, European Network for Accessible Tourism, 2019). Notwithstanding these efforts, the results still need to be evaluated and confirmed. For example, four times

\footnotetext{
1 An explanation of how this programme works can be found at https://www.aeroportolisboa.pt/en/lis/servicesshopping/essential-services/reduced-mobility
} 
more beaches were regarded as fully able to accommodate disabled users in 2020 than in 2005 (www.visitportugal.com), but the number (215) only represents about a quarter of all the beaches identified in the country. Finally, it is important to consider that the Tourism Strategy 2020-2027 for Portugal (www.turismodeportugal.pt) is grounded on 10 'global challenges' and one of them (no. 5) is titled 'Accessibilities: Reinforcing accessibility to Portugal and promoting mobility within the territory'.

\section{METHODOLOGY}

Most studies concentrating on disability theory and accessible tourism have incorporated various types of research methodologies (Naniopoulos, Tsalis, \& Nalmpantis, 2016). This study uses quantitative research through a questionnaire targeting upper-class accommodation units, with the purpose of fulfilling the aim/objectives and research questions. Additionally, it will attempt to discuss and compare Cyprus and Portugal concerning the adequacy of hotel facilities and services for GwD/GwSN. The study's aim, objectives and research question are presented in Table 3.

\begin{tabular}{|l|l|l|l|}
\hline Aim & \multicolumn{3}{|l|}{$\begin{array}{l}\text { To identify and compare the facilities offered in hotels in Cyprus and } \\
\text { Portugal to GwDs }\end{array}$} \\
\hline Objectives & $\begin{array}{l}\text { To identify the efficiency of } \\
\text { hotel } \\
\text { buildings/equipment/facilities } \\
\text { for GwD/GwSN }\end{array}$ & $\begin{array}{l}\text { To provide an } \\
\text { understanding on } \\
\text { the characteristics } \\
\text { of the market } \\
\text { (GwD/GwSN) }\end{array}$ & $\begin{array}{l}\text { To understand the } \\
\text { efficiency of the } \\
\text { human resources: } \\
\text { skills, procedures } \\
\text { and training } \\
\text { actions } \\
\text { considering } \\
\text { servicing } \\
\text { PwD/GwSN }\end{array}$ \\
\hline $\begin{array}{l}\text { Research } \\
\text { Questions }\end{array}$ & $\begin{array}{l}\text { Are hotel facilities provided } \\
\text { for GwDs/GwSN efficient? }\end{array}$ & $\begin{array}{l}\text { What are the } \\
\text { characteristics of } \\
\text { GwD/GwDs? }\end{array}$ & $\begin{array}{l}\text { Are employees } \\
\text { trained for service } \\
\text { delivery to } \\
\text { GwDs/GwSN? }\end{array}$ \\
\hline
\end{tabular}

Table 3: The study's aim, objectives, and research questions. Source: Authors. 
The primary research involved a self-administered questionnaire targeting $4^{*}$ and $5^{*}$ hotels in the two countries. ${ }^{2}$ The sample was non-probability purposive because it determined in advanced the type and ranking of the hotels targeted. The questionnaire was prepared in English using Google Forms and it was sent online targeting the General Managers of each hotel. In the case of Cyprus all $4^{*}$ and $5^{*}$ hotels with the total to be 76 were contacted and the final return rate was $100 \%$. In the case of Portugal 415 General Managers were contacted with a return rate of $17 \%$ (70 hotels). Given the difference in the sample size among the two countries this might implies that the results have been affected since the sample size from Portugal did not allow statistical validation. However, it had a similar dimension as that there is the sample obtained in Cyprus and this enabled to draw useful conclusions.

The steps followed involved an email either directly to the hotel General Managers or to the Front Desks with guidelines to be forwarded to the General Managers) requesting to participate in the research for academic purposes. The research did follow-up reminders thereafter and in some cases the hotels' General Managers were contacted by phone as a kind reminder to complete the questionnaire. Primary data collection in both Cyprus and Portugal took place from May 2018 until October 2019.

The questionnaire content was based on the existing literature concerning GwD/GwSN and hotels (Porto et al. 2020). It is divided in 3 Sections (Table 4). The sections were focused on the following topics: i) About the building/equipment/facilities; ii) About the characteristics of the market and iii) Human resources: skills, procedures, training actions considering GwD/GwSN. From the retrieved data, the questionnaires responses were calculated using descriptive statistics and the Wilcoxon test to analyse differences between distributions in the two countries. A significance level of $1 \%$ was used. For statistical purposes and in better accordance with the written scale, the initial 1 to 5 scale was converted to a -2 to 2 scale. We also used boxplots to illustrate these differences, allowing for a visual representation of minimum, median and maximum values as well as the distribution of the answers. Data were analysed using R software 4.0. The following part presents the results of the questionnaire data.

\footnotetext{
${ }^{2}$ Considering the typology, in Cyprus, Category A apartments were also considered.
} 


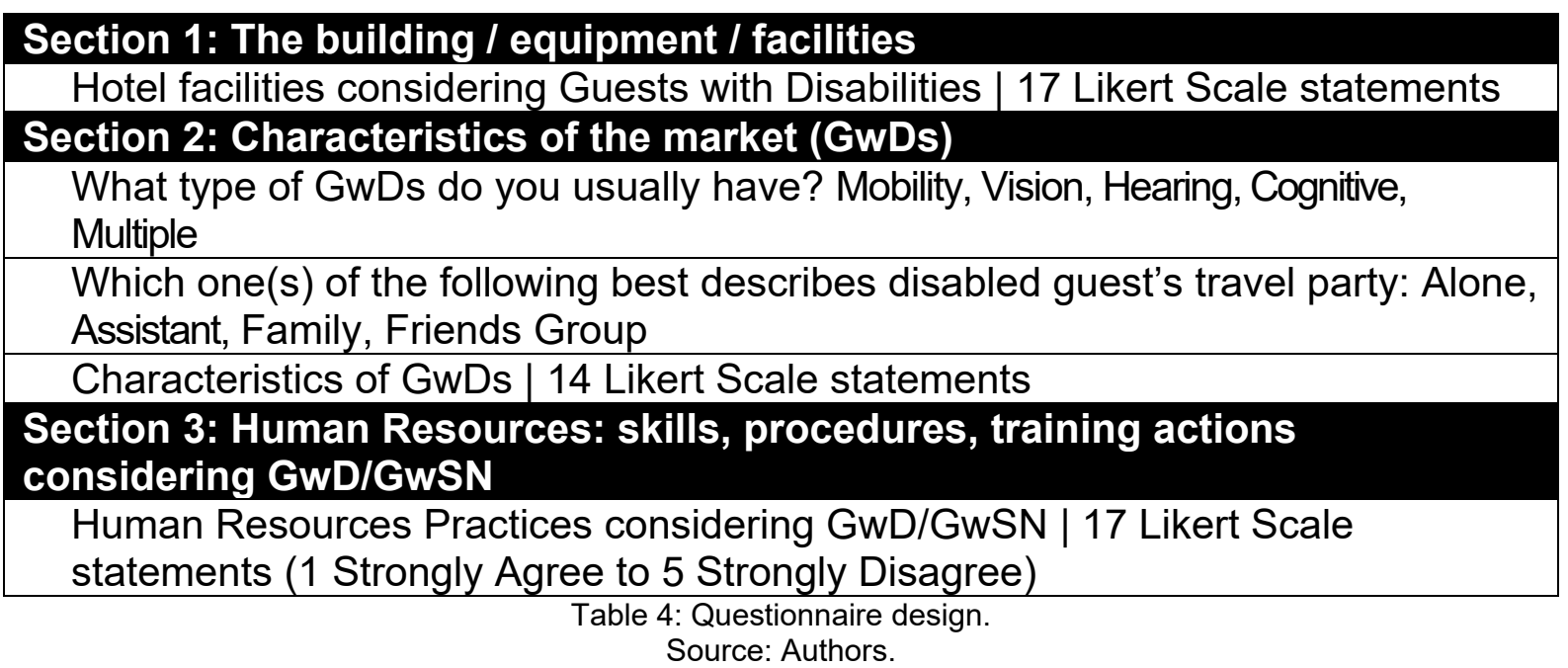

\section{RESULTS}

The first section of the questionnaire was focused on the physical conditions: the building, equipment and facilities on the ground. The average grade given to the 17 questions in the table is indicative, showing a strong degree of similarity between the countries: 3.7 in Cyprus and 3.5 in Portugal, considering a 1 (absolutely disagree) to 5 (absolutely agree) Likert scale. It is interesting to note that the most embracing single topic - 'The hotel has all the necessary equipment for GwDs' - has a higher average grade (3.8 in Portugal and 4.0 in Cyprus) than the one given to the full section, i.e. it seems that the first opinion the respondents had in mind was more optimistic than the result obtained through a refined assessment of the questions, one by one.

Some questions yielded similar results, whereas others revealed significant differences between the two countries, related to their distinctive architectural and management traditions. Finally, vision and hearing impairments as well as special activities for GwSN do not seem to be given the same amount of attention as mobility impairments (Table 5 and Figure 1, organised by medians, in a -2/0/+2 scale).

\begin{tabular}{|c|c|c|c|}
\hline Items & $\begin{array}{c}\text { Portugal } \\
-2 /+2 \\
(n=70) \\
\text { Median }\end{array}$ & $\begin{array}{c}\text { Cyprus } \\
-2 /+2 \\
(n=76) \\
\text { Median }\end{array}$ & $\begin{array}{c}P<0.01 \\
\text { (Wfilcoxon) }\end{array}$ \\
\hline \begin{tabular}{l|l} 
[The hotel has all the necessary \\
P1 equipment for GwDs]
\end{tabular} & 1.0 & 1.0 & \\
\hline $\begin{array}{l}\text { [All the facilities for GwDs are disabled- } \\
\text { P2 friendly] }\end{array}$ & 1.0 & 1.0 & \\
\hline
\end{tabular}




\begin{tabular}{|c|c|c|c|}
\hline \begin{tabular}{l|l} 
[The hotel offers a transfer vehicle for \\
P3 disabled guests]
\end{tabular} & 0.0 & 1.0 & * \\
\hline $\begin{array}{l}\text { [There is adequate parking for disabled } \\
\text { P4 guests] }\end{array}$ & 2.0 & 1.0 & \\
\hline $\begin{array}{l}\text { [The reception has an adequate ramp for } \\
\text { P5 access by disabled people] }\end{array}$ & 2.0 & 1.0 & * \\
\hline $\begin{array}{l}\text { [The reception counter is accessible to } \\
\text { P6 wheelchairs] }\end{array}$ & 2.0 & 1.0 & \\
\hline P7 [The hotel has an accessible elevator] & 2.0 & 1.0 & * \\
\hline \begin{tabular}{l|l} 
[The hallway is large enough to \\
P8 accommodate wheelchairs]
\end{tabular} & 2.0 & 1.0 & * \\
\hline $\begin{array}{l}\text { [The hotel has an important number } \\
\text { (above the law) of mobility-disabled guest } \\
\text { P9 rooms }]\end{array}$ & 0.0 & -1.0 & * \\
\hline \begin{tabular}{l|l} 
[In disabled guest rooms, the door is easy \\
P10 to open and to go through]
\end{tabular} & 1.0 & 1.0 & \\
\hline \begin{tabular}{l|l} 
[In disabled guest rooms, the closets are \\
P11 accessible]
\end{tabular} & 1.0 & 1.0 & \\
\hline \begin{tabular}{l|l} 
P12 & [In disabled guest rooms, the beds are \\
adjustable]
\end{tabular} & 0.0 & 1.0 & \\
\hline $\begin{array}{l}\text { [In disabled guest rooms, the balcony is } \\
\mathrm{P} 13 \text { accessible] }\end{array}$ & 1.0 & 1.0 & \\
\hline \begin{tabular}{l|l} 
[In disabled guest rooms, the bathroom is \\
$\mathrm{P} 14$ cosy and functional]
\end{tabular} & 1.0 & 1.0 & * \\
\hline $\begin{array}{l}\text { [The hotel has clear signs for the visually } \\
\text { P15 impaired] }\end{array}$ & 0.0 & 0.5 & \\
\hline $\begin{array}{l}\text { [The hotel has facilities for guests with } \\
\text { P16 hearing impairments] }\end{array}$ & 0.0 & -1.0 & \\
\hline \begin{tabular}{l|l} 
P17here are special activities for disabled \\
guests in the hotel]
\end{tabular} & -1.0 & -1.0 & \\
\hline
\end{tabular}

Table 5: About the building/equipment/facilities.

Scale used from absolutely disagree $(-2)$ to absolutely agree (+2) Likert scale.

* Statistical significance at 0.01 level.

Source: Authors. 


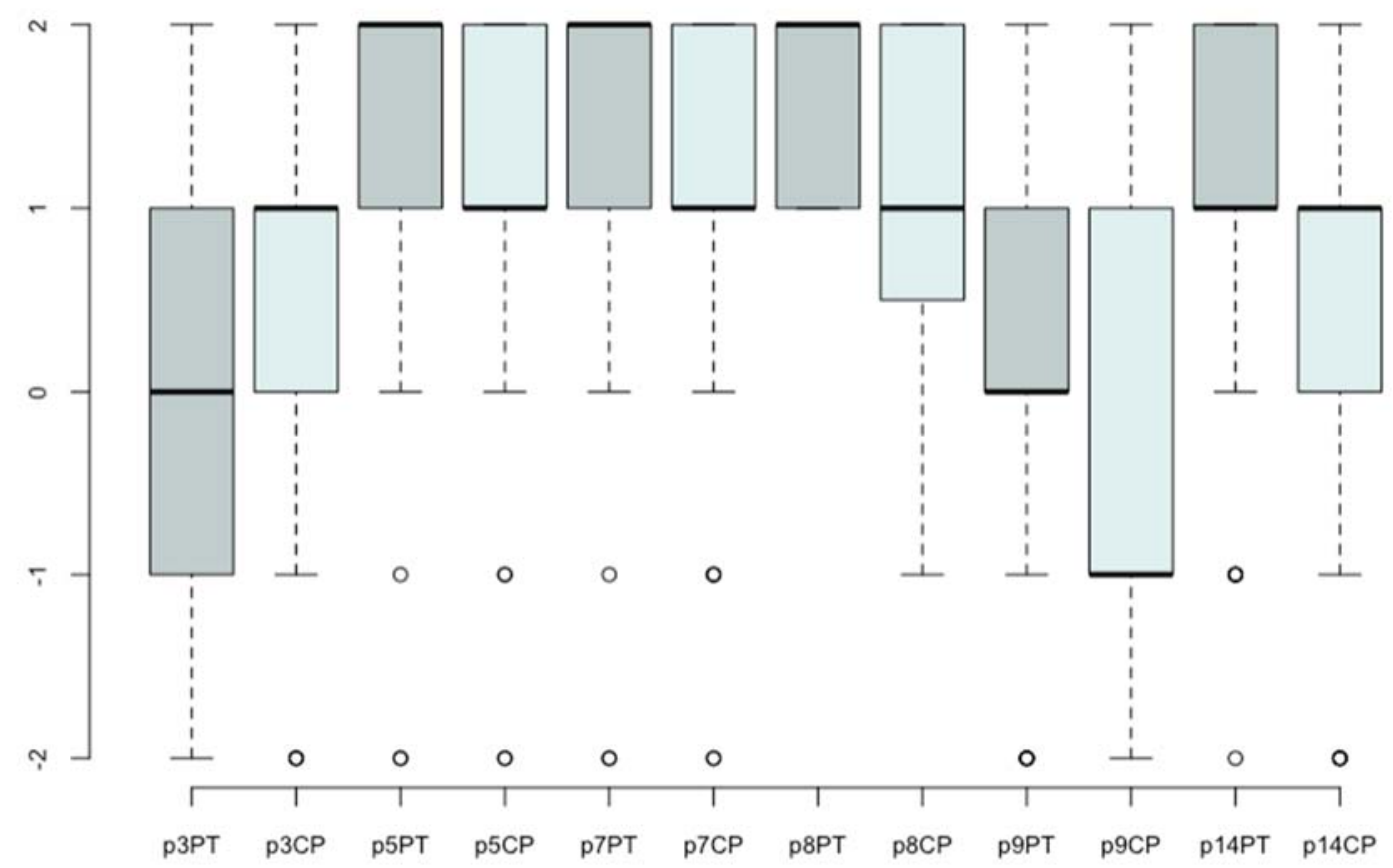

Figure 1: Boxplots representing the distribution of answers for both countries, only for variables in which differences were found - Section A. Source: Authors.

The characteristics of the market (GwSN) are analysed in two sub-sections, considering different solutions for grading (Tables 6 and 7). In the first one, the hotels were asked about their guests' types of special needs and travelling parties: respondents could choose one or more options. The results reveal an interesting diversity of cultural approaches: in Portugal attention is more focused on a specific impairment/disability (mobility being the most frequent and visible), while interpretations of a multiple impairment condition are quite rare, whereas in Cyprus this represents $53.9 \%$ of the answers. On the other hand, the possibility of a double or triple choice in Portugal has greater representation than in Cyprus (101 points considering a sample of 70 hotels in Portugal, compared with 78 points in a sample of 76 hotels in Cyprus).

Regarding disabled guests' travelling parties, the family is the most common option, especially in Portugal, as in Cyprus personal assistants are also popular. 


\begin{tabular}{|c|c|c|}
\hline & $\begin{array}{c}\text { Portugal } \\
(n=70)\end{array}$ & $\begin{array}{l}\text { Cyprus } \\
(n=76)\end{array}$ \\
\hline \multicolumn{3}{|c|}{$\begin{array}{l}\text { What types of GwSN do you } \\
\text { usually have? }\end{array}$} \\
\hline Cognitive & (7) $10.0 \%$ & (1) $1.3 \%$ \\
\hline Hearing & (10) $14.3 \%$ & (2) $2.6 \%$ \\
\hline Mobility & (70) $100.0 \%$ & (33) $43.4 \%$ \\
\hline Vision & (9) $12.9 \%$ & (1) $1.3 \%$ \\
\hline \multirow{2}{*}{ Multiple } & (5) $7.1 \%$ & (41) $53.9 \%$ \\
\hline & Total $=101$ & Total $=78$ \\
\hline \multicolumn{3}{|c|}{$\begin{array}{l}\text { Which of the following best } \\
\text { describes disabled guests' } \\
\text { travelling parties? }\end{array}$} \\
\hline Alone & (3) $4.3 \%$ & (2) $2.6 \%$ \\
\hline Family & (67) $95.7 \%$ & (36) $47.4 \%$ \\
\hline Friends & (12) $17.1 \%$ & (11) $14.5 \%$ \\
\hline Group & (15) $21.4 \%$ & (11) $14.5 \%$ \\
\hline \multirow[t]{2}{*}{ Personal assistant } & (5) $7.1 \%$ & (20) $26.3 \%$ \\
\hline & Total $=102$ & Total $=80$ \\
\hline
\end{tabular}

Table 6: About the characteristics of the market (GwSN)|A. Source: Authors.

Section B includes the results for a set of 14 questions regarding the personal characteristics of the market (GwSN). Using the 1 (absolutely disagree) to 5 (absolutely agree) Likert scale, for the assessment of statements where a market differentiation was suggested, the average grade is only about 3.0 in Portugal and 2.9 in Cyprus. Only in two topics - 'Disabled guests seek more attention from hotel staff' and 'Disabled guests are more loyal customers' - do the answers indicate a significant degree of national influence. In both countries, the respondents tend to consider that GwSN as consumers contribute the same to the hotel as all other guests (Table 6, also organised by medians, in a $-2 / 0 /+2$ scale).

\begin{tabular}{|c|c|c|c|c|}
\hline & Items & $\begin{array}{c}\text { Portugal } \\
-2 /+2 \\
(n=70) \\
\text { Median }\end{array}$ & $\begin{array}{c}\text { Cyprus } \\
-2 /+2(n=76) \\
\text { Median }\end{array}$ & $\begin{array}{c}P<0.01 \\
\text { (Wflcoxon) }\end{array}$ \\
\hline P20 & $\begin{array}{l}\text { [Disabled guests book their } \\
\text { accommodation directly from the } \\
\text { internet] }\end{array}$ & 1.0 & 1.0 & \\
\hline P21 & $\begin{array}{l}\text { [Disabled guests book the hotel online } \\
\text { or using a travel agency] }\end{array}$ & 1.0 & 1.0 & \\
\hline P22 & $\begin{array}{l}\text { [There are more disabled guests during } \\
\text { the low season] }\end{array}$ & 0.0 & 0.0 & \\
\hline
\end{tabular}




\begin{tabular}{|c|l|c|c|c|}
\hline P23 & $\begin{array}{l}\text { [The average age of disabled guests is } \\
\text { the same as all other guests] }\end{array}$ & 1.0 & 0.0 & $*$ \\
\hline P24 & $\begin{array}{l}\text { [The average duration of occupancy of } \\
\text { disabled guests is longer] }\end{array}$ & 0.0 & -0.5 & $*$ \\
\hline P25 & $\begin{array}{l}\text { [Disabled guests spend more time in } \\
\text { the hotel] }\end{array}$ & 0.0 & 0.0 & \\
\hline P26 & $\begin{array}{l}\text { [Disabled guests tend to spend most of } \\
\text { their time in their room] }\end{array}$ & 0.0 & 0.0 & \\
\hline P27 & $\begin{array}{l}\text { [Disabled guests make more orders for } \\
\text { room service] }\end{array}$ & 0.0 & 0.0 & \\
\hline P28 & $\begin{array}{l}\text { [The average spending of disabled } \\
\text { guests at the hotel is higher] }\end{array}$ & 0.0 & 0.0 & \\
\hline P29 & $\begin{array}{l}\text { [Disabled guests seek more attention } \\
\text { from hotel staff] }\end{array}$ & 0.0 & 1.0 & $*$ \\
\hline P30 & $\begin{array}{l}\text { [Disabled guests do not feel confident } \\
\text { about communicating with hotel staff] }\end{array}$ & -1.0 & -1.0 & \\
\hline P31 & {$[$ Disabled guests are more demanding] } & 0.0 & -1.0 & $*$ \\
\hline P32 & {$[$ [Disabled guests complain more] } & 0.0 & -1.0 & $*$ \\
\hline P33 & $\begin{array}{l}\text { [Disabled guests are more loyal } \\
\text { customers] }\end{array}$ & 0.0 & -1.0 & $*$ \\
\hline
\end{tabular}

Table 7: About the characteristics of the market (GwSN) | B

Scale used from absolutely disagree $(-2)$ to absolutely agree (+2) Likert scale.

* Statistical significance at 0.01 level.

Source: Authors.

We can note significant differences between the two countries relating to the average age of GwSN (P23), which seems to be like other guests in Portugal (63\% answers between 0 and 1), but not in Cyprus (58\% of answers between -1 and 0 ). Although the differences are small, the average duration of occupancy (P24) is longer in Portugal, seeing more answers on the agreement points, while Cyprus has a larger number of respondents on the disagreement points. Guests in Cyprus also seem to seek more attention from hotel staff (P29), with 82\% of answers being between 1 and 2, while in Portugal, 69\% of the answers range from 0 to -2 (Figure 2). Portuguese hotels are less certain about the demands and complaints of guests, with a higher percentage of answers being neither agree nor disagree, while for Cyprus, the answers tend to be on the disagreement values. The same is observed for the loyalty of guests (P31 to P33). 


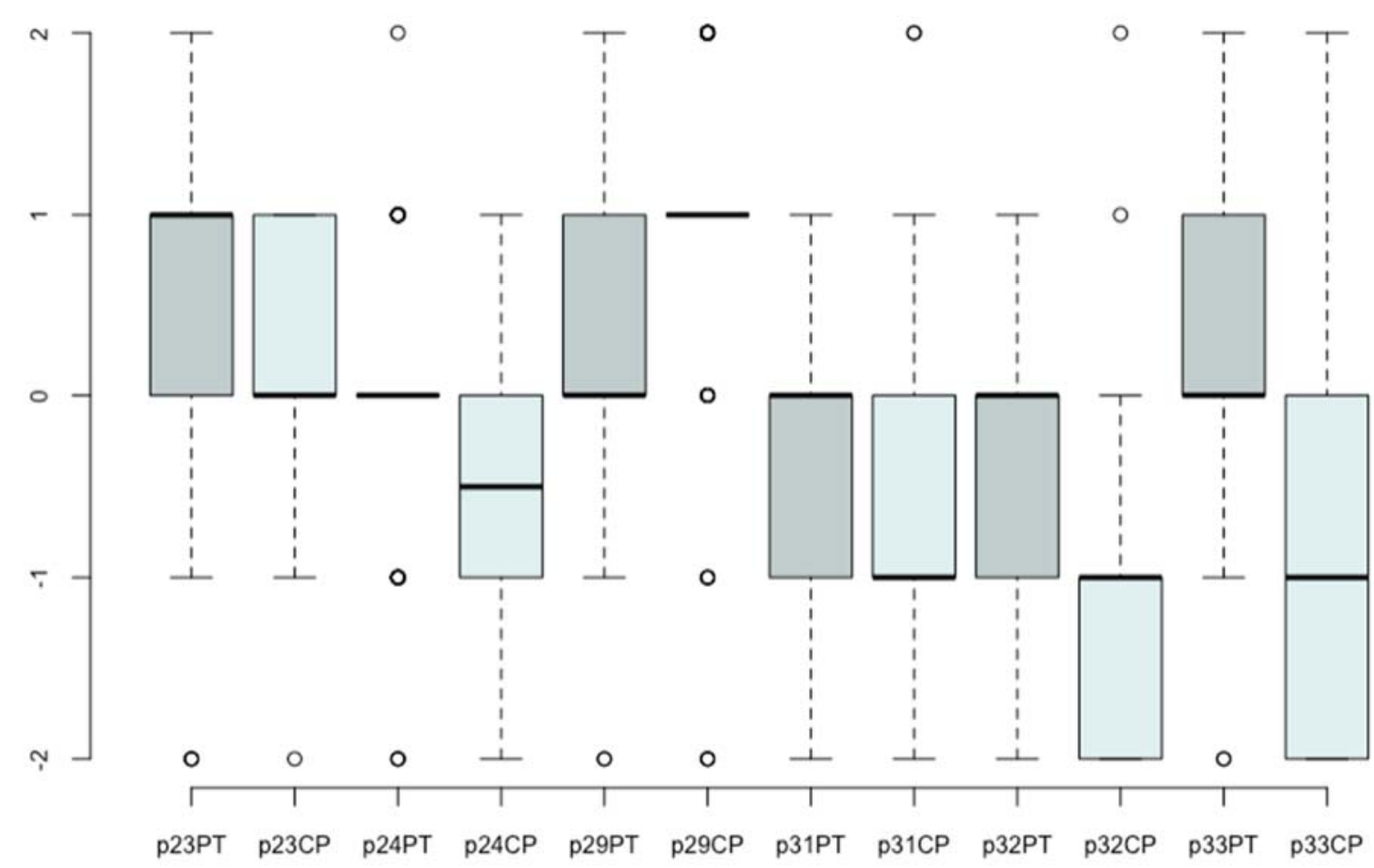

Figure 2: Boxplots representing the distribution of answers for both countries for variables in which differences were found - Section B. Source: Authors.

The final section of the questionnaire also reveals some interesting results and differences between the two countries. At first sight, it seems that in general the respondents from Cyprus were more positive about the services they can provide to GwSN, but on the other hand, they were less confident about the existence of an ongoing training process to improve such skills. The low grades given to the statements 'It is hard to serve disabled guests' and 'Employees complain when they have to service GwDs' show that this kind of service was not seen as a problem or a huge difficulty. The low grades given in both countries (2.6 and 3.0) to the topic 'A specialised staff is needed for disabled guests' may be interpreted from two contrasting points of view: it may be seen as a high level of confidence in the soft skills of the 'regular' staff, or as a troublesome ignorance about the real needs of such guests (Table 7 , once again organised by medians, in a $-2 / 0 /+2$ scale).

Regarding P34, the Portuguese have a more 'average/defensive' answer (39\% graded 0 , while $27 \%$ graded -1 or -2 and $34 \%$ graded 1 or 2 ). In Cyprus, the grade 0 is almost irrelevant (5\%), while $16 \%$ graded -1 or -2 and as many as $79 \%$ graded 1 or 2. There is also a relevant difference in staff including employees who know how to 
communicate with persons with hearing disabilities (P36). In Portugal, the majority $(60 \%)$ of answers fall into the disagreement points, whereas in Cyprus the opposite is observed (83\% between 1 and 2). The smallest difference can be observed in knowing how to communicate with persons with cognitive disabilities (P37), but with answers falling within the same pattern. The differences regarding P41 and P46 are less relevant (Figure 3). Few respondents opted to make final comments. Some comments were organised to highlight the work done with the front office departments, in accordance with the concern with 'Health and safety training, including first aid'.

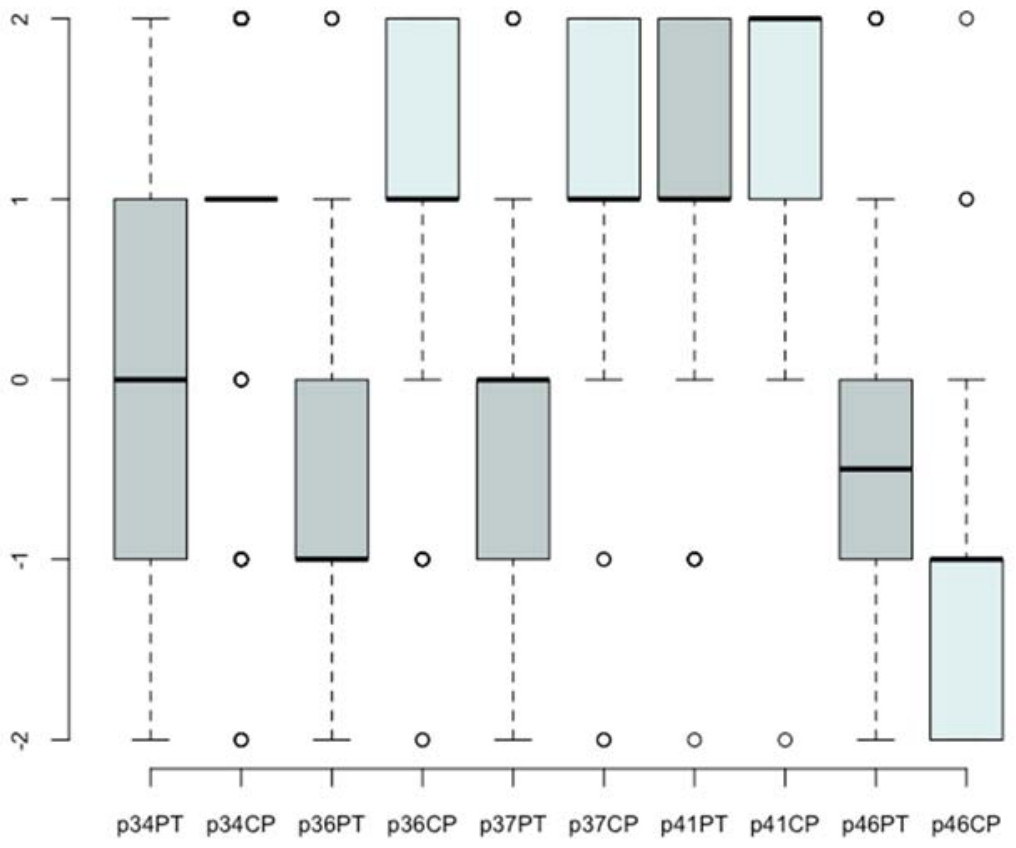

Figure 3: Boxplots representing the distribution of answers for both countries for the variables in which differences were found - Section C.

Source: Authors.

\section{DISCUSSION AND CONCLUSION}

This article complements the existing literature on disability and tourism by combining on the issue as an important aspect that needs further consideration (Chernaya et al., 2019). Undoubtedly, GwSN have the right to be included in tourism and the provision of services matching their needs is imperative (Darcy, 2019; Porto et al., 2020). The results of this study are indicative, identifying both differences and similarities between the two countries in terms of GwSN and hotels. Caring for both 
PwD and senior guests can engender a plethora of opportunities, most notably increased tourism demand (Casaccia, Garofalo \& Marchesano, 2017; Huber, Milne \& Fyde, 2018; Var et al., 2011). Undoubtedly, this cohort of the market has the urge and desire to travel and participate in tourism and thus it should be seriously considered and included in these and other countries' tourism strategies (Koo Lee et al., 2012). Hotel General managers in both countries claimed to have facilities to accommodate mainly people with mobility disabilities. Other forms of disabilities are somewhat neglected, with limited or non-existent facilities and services. This is something that both countries should seriously consider by upgrading their services to include all types of GwD. This will help improve their image as all-inclusive, accessible destinations. This market has great potential and both countries' hotel industries must seize the opportunity to attract PwD and the people accompanying them, including family, friends, and other possible caregivers (Bowtell, 2015).

The profile of the market composing GwD/GwSN is rather different between the two countries. In Portugal, GwD/GwSN have the same age range whereas in Cyprus there is a difference compared to other guests. In general, the results suggest that GwD/GwSN, even though they are not regarded as more demanding guests and do not complain more often, are not considered to be loyal customers. This may imply that dissatisfied GwD/GwSN do not express any complaints or disappointment because they do not consider the hotel or the destination as a future option for their holidays (Tchetchik et al., 2018). The results of this study also indicate as the most important outcome a limitation in employees' ways of communicating and serving GwD/GwSN (Agovino et al., 2017), especially people with hearing disabilities. Hotels in both countries should seriously consider including training schemes for employees regarding how GwD/GwSN should be treated and served. This reflects the belief that GwD/GwSN are not deemed to be loyal customers and may derive from the fact that services and facilities are currently insufficient and not adjusted to these guests' needs (Bisschoff \& Breedt, 2012). The research enhances the existing literature by showing that disabled facilities in hotels should be adequate not only for people with mobility impairments but also for people with other types of disabilities that remain somewhat neglected (Var et al., 2011). Thus, understanding the diversity of GwD/GwSN and adjusting to their needs by providing the right facilities and services is imperative for hotels and destinations (Burns et al., 2009). 
This study has managerial implications in terms of how tourism practitioners and especially employees understand the needs of GwD/GwSN. This is of paramount importance today, because this cohort of the market is increasing and access should be ensured to all in tourism, by establishing appropriate physical facilities and human services. Especially in the cases of Cyprus and Portugal, their economies are highly dependent on tourism and the exclusion of PwD acts against their visions for expanding and diversifying their tourism activities. Incorporating full services to all GwD/GwSN can positively affect the image of both countries not only economically but also socially (Kalargyrou et al., 2020). Being a destination that provides services to GwD/GwSN should be high on the tourism agenda by understanding and providing for their special needs. Thus, destinations that are proponents in disability services are a step ahead by gaining greater market share and building on an image of being friendly to people without discriminating through offering exceptional tourism experiences both to GwD/GwD and their caregivers (Lehto et al., 2018). Hotel providers and employees must understand that GwD/GwSN (including senior travellers) choose a hotel based on its facilities, adequate customer service and previous GwD/GwSN experiences at the hotel (Chernaya et al., 2019; Ancell \& Graham, 2016). The results suggest that the focus should be not only on physical aspects (including facilities for all GwSN) but also on human resources and services (Poria et al., 2011).

Based on the results of this research, four main pillars of focus can be suggested to improve service provision in hotels not only in Cyprus and Portugal but also in other countries that are highly dependent on tourism. The results suggest that intensive training schemes are required to the Managers and Employees for familiarisation with every type of disability by addressing the UN Convention and other regulations. Training seems to be the cornerstone and is addressed in the literature by developing intensive programmes dealing with the needs of this cohort of guests (Kalargyrou et al., 2020; Darcy \& Pegg, 2011). A thorough understanding of every type of disability needs should be set as a priority to clearly explain how GwD/GwSN differ from other guests (Kalargyrou et al., 2020). In particular, the hotels must pursue to apply 'Service4ALL' approach that is based in four pillars:

These pillars are:

1. Development of questionnaire targeting GwD and GwSN feedback concerning the services provided. 
2. Development of manuals to provide an understanding of GwD and GwSN types and needs by assigning specific staff to exclusively serve GwD and GwSN;

3. Development of detailed guidelines (though manuals) describing the procedures when dealing with service to GwD and GwSN: maintain loyalty;

4. Intensive training schemes for employees for applying services to GwD and GwSN (different sessions for each type of Disability) - workshops, seminars, tutorials.

In Figure 4, pillar four is considered by depicting the training schemes that should be conducted mainly by Human Resources Managers along with departmental Managers. Achieving high standards of disabled-friendly services will affect competitiveness and ensure the viability of the hotel. Additionally, the results of this study suggest that both Cyprus and Portugal must pursue a framed policy and regulatory framework addressing the issue of accessible tourism in hotels, to become essential providers for facilities and services for GwD/GwSN.

\section{Instructor led Training}

Guest Speakers

(PwD),Tutorials,Seminars

UN Convention and other regulations

Presentation of $\mathrm{GwD} / \mathrm{GwSN}$

questionnaires feedback

Determine the needs

Manuals

\section{Mentoring and Coaching}

Enable employees to provide services to GwD - Assigned external associates, experienced employees to provide guidance and act as coaches or mentors.

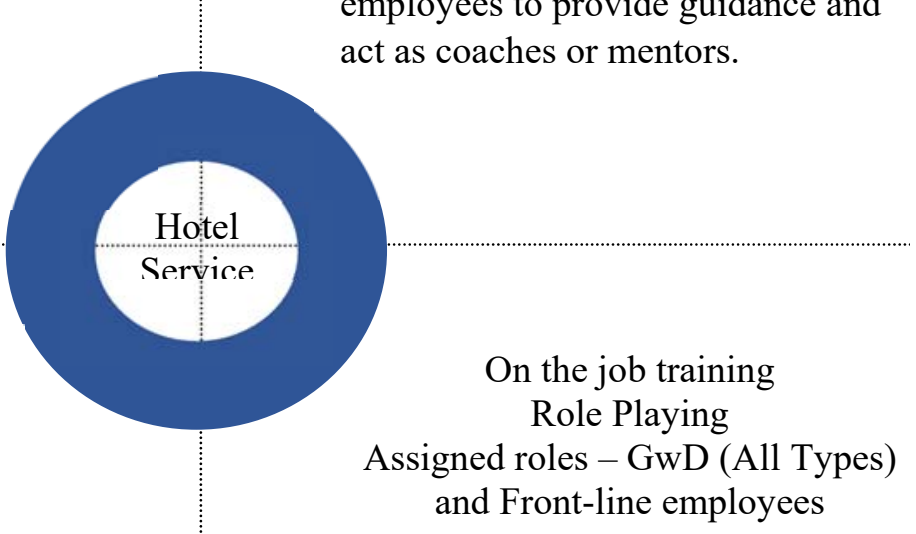

Soft skills development

Hard skills development

Figure 4: Hotel Services 4ALL. Source: Authors. 


\section{LIMITATIONS AND FUTURE RESEARCH}

This research should be regarded as a steppingstone for further research by considering the views and opinions of PwSN in terms of hotel services in both Cyprus and Portugal. Further research should also separate each type of disability and assess the provision of services offered (or not) in hotels. Moreover, consideration of the views and opinions of PwD/PwSN in terms of the adequacy of hotel services both in Cyprus and Portugal merits attention. An additional research idea is to expand and discuss the facilities and services of other sectors of the industry to compare and draw useful conclusions. Furthermore, it is necessary to develop a framework of hotel training schemes for employees by addressing the needs of PwD/PwSN and how they should be served and treated during their stay in hotels. Finally, it is important to understand the policy remits emanating from governmental endeavours to establish Cyprus and Portugal as accessible destinations and to postulate a new image for both countries. In conclusion, research addressing the issue of disability should be at the top of the national tourism policy agenda because of the plethora of implications for destinations and PwD/PwSN. It should be seriously considered that tourism is a priority for the economic and social viability of destinations like Portugal and Cyprus because they are highly dependent on it.

Research sample in terms of the imbalance of the hotels' number among Cyprus and Portugal consist of a limitation. However, this can be considered as new research opportunity by collecting more data from Portugal so as the conclusion can be more accurate. Another limitation is the fact that the collected data is retrieved from managers' views about GwD facilities offered in hotel without considering the views of the GwD. Additional research can be to consider the views of $G w D$ and the preparedness of the hotels in the offering of special facilities and services.

\section{References}

Agovino, M.; Casaccia, M.; Garofalo, A.; Marchesano, K. Tourism and disability in Italy. Limits and opportunities. Tourism Management Perspectives, Vol. 23, 2017, pp. 5867. 
Ambrose, I. European policies for accessible tourism'. In Buhalis, D.; Darcy, S.; Ambrose, I (Eds.). Best practice in accessible tourism: Inclusion, disability, ageing population, and tourism. Bristol: Channel View, 2012, pp. 19-35.

Ambrose, I. The impact of accessible tourism. Retrieved from https://www.accessibletourism.org/resources/hti 2016 ambroseimpact of accessible tourism-small.pdf [accessed 4 November 2021].

Ancell, D.; Graham, A. A framework for evaluating the European airline costs of disabled persons and persons with reduced mobility. Journal of Air Transport Management, Vol. 50, 2016, pp. 41-44.

Benjamin, S.; Bottone, E.; Lee, M. Beyond accessibility: exploring the representation of people with disabilities in tourism promotional materials. Journal of Sustainable Tourism, Vol. 29, No. 2-3, 2021, pp. 295-313.

Bi, Y.; Card, J.A.; Cole, S.T. Accessibility and attitudinal barriers encountered by Chinese travellers with physical disabilities. International Journal of Tourism Research, Vol. 9, No.3, 2007, pp. 205-216.

Bisschoff C.A.; Breedt T.F. The need for disabled friendly accommodation in South Africa. African Journal of Business Management, Vol. 6, No. 41, 2012, pp. 1053410541.

Bizjak, B.; Knezevic, M.; Cvetreznic, S. Attitude change towards guests with disabilities. Reflections from tourism students. Annals of Tourism Research, Vol. 38, No. 3, 2011, pp. 842-857.

Blichfeldt, B.; Nicolaisen, J. Disabled travel: not easy but doable. Current Issues in Tourism, Vol. 14, No. 1, 2011, pp. 79-102. 
Bowtell, J. Assessing the value and market attractiveness of the accessible tourism industry in Europe: a focus on major travel and leisure companies. Journal of Tourism Futures, Vol. 1, No. 3, 2015, pp. 203-222.

Buhalis, D.; Michopoulou, E. Information-Enabled Tourism Destination Marketing: Addressing the Accessibility Market. Current Issues in Tourism, Vol. 14, No. 2, 2011 , pp. 145-168.

Burnett, J.; Baker, H. Assessing the travel-related behaviors of the mobility-disabled consumer. Journal of Travel Research, Vol. 40, No. 1, 2001, pp. 4-11.

Burns, N.; Paterson, K.; Watson, N. An inclusive outdoors? Disabled people's experiences of countryside leisure services. Leisure Studies, Vol. 28, No. 4, 2009, pp. 403-417.

Carlzon, J. Moments of Truths - New Strategies for Todays' Customer-driven Economy. New York: Harper Collins, 1987.

Caro, S.N.; Waal, A.; Buhalis, D. Special needs customer care training for tourism. In Buhalis, D.; Darcy, S.; Ambrose, I. (Eds.). Best practice in accessible tourism: Inclusion, disability, ageing population, and tourism. Bristol: Channel View, 2012, pp. 365-375.

Casaccia, M.; Garofalo, A.; Marchesano, M. Tourism and disability in Italy. Limits and opportunities. Tourism Management Perspectives, Vol. 23, 2017, pp. 58-67.

Chang, Y.; Chen, C. Meeting the needs of disabled air passengers: factors that facilitate help from airlines and airports. Tourism Management, Vol. 33, No. 3, 2012, pp. 529-536.

Chang, Y.; Chen, F. Overseas travel choice for persons with reduced mobility. Journal of Air Transport Management, Vol. 20, 2012a, pp. 43-45. 
Chernaya, V.; Moreira, P.; Chizhova, V.; Kulakova, N. Development of medical and ecological tourism for physically challenged people and people with disabilities in the Ryazan region. International Journal of Healthcare Management, Vol. 14, No. 2, 2019, pp. 1-6.

Daniels, M.; Rodgers, E.; Wiggins B. "Travel Tales": an interpretive analysis of constraints and negotiations to pleasure travel as experienced by persons with disabilities. Tourism Management, Vol. 26, No. 6, 2005, pp. 919-930.

Darcy, S.; Pegg, S. Towards strategic intent: Perceptions of disability service provision amongst hotel accommodation managers. International Journal of Hospitality Management, Vol. 30, No. 2, 2011, pp. 468-476.

Darcy, S. Inherent complexity: disability, accessible tourism and accommodation information preferences. Tourism Management, Vol. 31, No. 6, 2010, pp. 816-826.

Darcy, S. Leisure with impact: research, human rights, and advocacy in a reflective review of a research career. Annals of Leisure Research, Vol. 22, No. 3, 2019, pp. 273285.

Darcy, S.; Cameron, B.; Pegg, S. Accessible tourism and sustainability: a discussion and case study. Journal of Sustainable Tourism, Vol. 18, No. 4, 2010, pp. 515-537.

Deal, T.E.; Kennedy, A.A. Corporate Cultures. The Rites and Rituals of Corporate Life. Reading, MA: Addison-Wesley, 1982.

Devile, E.; Kastenholz, E. Accessible tourism experiences: the voice of people with visual disabilities. Journal of Policy Research in Tourism, Leisure and Events, Vol. 10, No. 3, 2018, pp. 265-285.

Devine, M. Being a 'Doer' Instead of a 'Viewer': The Role of Inclusive Leisure. Journal of Leisure Research, Vol. 36, No. 2, 2004, pp. 137-159. 
Disability Forum. Disability-Smart Awards: Why it matters. 2018. Retrieved from https://businessdisabilityforum.org.uk/news-opinion/disability-smart-awards-why-itmatters/ [accessed 26 November 2021].

Disabled World. Disabled World Travel: Accessible Disability Travel Information. Retrieved from http://www.disabled-world.com/travel/ [accessed 2 November 2021].

ECS - European Committee for Standardization. CEN/TC 329 Tourism Services. Retrieved from https://standards.cencenelec.eu/ [accessed 25 November 2021].

ENAT - European Network for Accessible Tourism. San Sebastian Wins UNWTO Award for Sustainability \& Governance While Portugal Named Most Accessible. Retrieved from https://www.accessibletourism.org/?i=enat.en.news.2142 [accessed 14 May 2019].

Ernst and Young. The hospitality sector in Europe. Retrieved from https://www.hospitalitynet.org/file/152005191.pdf [accessed 25 November 2021].

European Commission. Improving information on accessible tourism for disabled people, Italy. 2004. Retrieved from http://ec.europa.eu/enterprise/sectors/tourism/files/studies/improving information on accessibility/improving accessibility en.pdf [accessed 24 November 2019].

European Commission. EU National Accessibility Legislation and the Tourism Sector. 2014. Retrieved from https://op.europa.eu/en/publication-detail/Ipublication/37988a99-87b7-426a-8a62-6f2227e74424 [accessed 25 November 2021].

European Commission. EU parking card for people with disabilities. 2019. Retrieved from https://europa.eu/youreurope/citizens/travel/transport-disability/parking-carddisabilities-people/index en.htm [accessed 30 November 2019]. 
European Disability Forum. How many persons with disabilities live in the EU? 28.11.2019. Retrieved from https://www.edf-feph.org/newsroom-news-how-manypersons-disabilities-live-eu/ [accessed 25 November 2021].

European Parliament. Regulation (EC) No 1107/2006 of the European Parliament and of the Council of 5 July 2006 concerning the rights of disabled persons and persons with reduced mobility when travelling by air. Retrieved from https://eurlex.europa.eu/legal-content/EN/ALL/?uri=CELEX\%3A32006R1107 [accessed 20 June 2019].

Fernández Alles, M.T. Turismo accesible. Análisis de la accesibilidad hotelera en la provincia de Cádiz. Cádiz: Universidad de Cádiz, 2007.

Figueiredo, E.; Eusébio, C.; Kastenholz, E. How Diverse are Tourists with Disabilities? A Pilot Study on Accessible Leisure Tourism Experiences in Portugal. International Journal of Tourism Research, Vol. 14, No. 6, 2012, pp. 531-550.

Gillovic, B.; Mclntosh, A.; Darcy, S.; Cockburn-Wootten, C. Enabling the language of accessible tourism. Journal of Sustainable Tourism, Vol. 26, No. 4, 2018, pp. 615-630.

Grady, J.; Ohlin, J. Equal access to hospitality services for guest with mobility impairments under the Americans with Disabilities Act: implications for the hospitality industry. International Journal of Hospitality Management, Vol. 28, No. 1, 2009, pp. 161-169.

Gröschl, S. An exploration of HR policies and practices affecting the integration of persons with disabilities in the hotel industry in major Canadian tourism destinations. International Journal of Hospitality Management, Vol. 26, No. 3, 2007, pp. 666-686.

Huber, D.; Milne, S.; Fyde, K. Constraints and facilitators for senior tourism. Tourism Management Perspectives, Vol. 27, 2018, pp. 55-67. 
Hughes, B.; Paterson, K. The Social Model of Disability and the Disappearing Body: Towards a sociology of impairment. Disability \& Society, Vol. 12, No. 3, 1997, pp. 325340.

ISO - International Organization for Standardization. ISO/TC 228 Tourism and related services. 2019. Retrieved from https://www.iso.org/committee/375396.html [accessed 30 October 2019].

Kalargyrou, V.; Trivellas, P.; Sigala, M. Guests' stereotyping, and quality evaluations of service delivered by employees with disabilities: does service failure matter? Asia Pacific Journal of Tourism Research, Vol. 25, No. 7, 2020, pp. 735-752.

Kastenholz, E.; Eusébio, C.; Figueiredo, E. Contributions of tourism to social inclusion of persons with disability. Disability \& Society, Vol. 30, No. 8, 2015, pp. 1259-1268.

Koo Lee, B.; Agarwal, S.; Kim, H. Influences of travel constraints on the people with disabilities' intention to travel: An application of Seligman's helplessness theory. Tourism Management, Vol. 33, No. 3, 2012, pp. 569-579.

Landby, E. Everyday travel for families with children using wheelchairs: parents' perceptions of constraints and adaptation strategies. Children's Geographies, Vol. 17, No. 4, 2019, pp. 388-400.

Lehto, X.; Luo, W.; Miao, L.; Ghiselly, R. Shared tourism experience of individuals with disabilities and their caregivers. Journal of Destination Marketing \& Management, Vol. 8, 2018, pp. 185-193.

Liasidou, S.; Umbelino, J.; Amorim, É. Revisiting tourism studies curriculum to highlight accessible and inclusive tourism. Journal of Teaching Travel and Tourism, Vol. 19, No. 2, 2019, pp. 112-125.

Lyu, S. Which accessible travel products are people with disabilities willing to pay more? A choice experiment. Tourism Management, Vol. 59-C, 2017, pp. 404-412. 
Mavrou, K.; Liasidou, A. ANED 2012 Task 4: National Accessibility Report Cyprus. Retrieved from http://www.disabilityeurope.net/content/aned/media/ANED\%202012\%20-\%20CY\%20\%20Task\%204\%20-\%20National\%20Accessibility\%20Report\%20FINAL.doc [accessed 15 June 2019].

McCabe, S.; Minnaert, L.; Diekmann, A. Social Tourism in Europe: Theory and Practice. Bristol: Channel View Publications, 2011.

McKercher, B.; Darcy, S. Re-conceptualizing barriers to travel by people with disabilities. Tourism Management Perspectives, Vol. 26, 2018, pp. 59-66.

Michopoulou, E.; Darcy, S.; Ambrose, I.; Buhalis, D. Accessible tourism futures: the world we dream to live in and the opportunities we hope to have. Journal of Tourism Futures, Vol. 1, No. 3, 2015, pp. 179-188.

Ministry of Commerce, Industry and Tourism of Cyprus, MCIT 2017. Cyprus Tourism Strategy 2017-2030. Retrieved from https://www.tourism.gov.cy/tourism/tourism.nsf/All/C47787D51281C03CC225850D00 287C68/\$file/Cyprus\%20Tourism\%20Strategy\%202030\%20-

\%20Presentation.pdf?OpenElement [accessed 25 November 2021].

Minnaert, L. Social Tourism as Opportunity for Unplanned Learning and Behavior Change. Journal of Travel Research, Vol. 51, No. 5, 2012, pp. 607-616.

Minnaert, L.; Maitland, R.; Miller, G. Tourism and social policy - The value of social tourism. Annals of Tourism Research, Vol. 36, No. 1, 2009, pp. 316-332.

Minnaert, L.; Maitland, R.; Miller, G. What is social tourism? Current Issues in Tourism, Vol. 14, No. 5, 2011, pp. 403-415. 
Murray, M.; Sproats, J. The disabled traveller: Tourism and disability in Australia. Journal of Tourism Studies, Vol. 1, No. 1, 1990, pp. 9-14.

Naniopoulos, A.; Tsalis, P.; Nalmpantis, D. An effort to develop accessible tourism in Greece and Turkey: the MEDRA project approach. Journal of Tourism Futures, Vol. 2, No. 1,2016 , pp. $56-70$.

Navarro, S.; Garzón, D.; Roig-Tierno, N. Co-creation in hotel-disable customer interactions. Journal of Business Research, Vol. 68, No. 7, 2015, pp. 1630-1634.

Nickson, D. Human Resources Management for the hospitality and tourism industries. Oxford: Butterworth-Heinemann, 2007.

Ozturk, Y.; Yaylin, O.; Yesiltas, M. Is the Turkish tourism industry ready for a disabled customer's market? The views of hotel and travel agency managers. Tourism Management, Vol. 29, No. 2, 2008, pp. 382-389.

Packer, T.; McKercher, B.; Mathew K. Understanding the complex interplay between tourism, disability and environmental contexts. Disabilities and Rehabilitation, Vol. 29, No. 4, 2007, pp. 281-292.

Pagan, R. How important are holiday trips in preventing loneliness? Evidence for people without and with self-reported moderate and severe disabilities. Current Issues in Tourism, Vol. 23, No. 11, 2019, pp. 1394-1406.

Poria, Y.; Reichel, A.; Brandt, Y. Dimensions of hotel experience of people with disabilities: an exploratory study. International Journal of Contemporary Hospitality Management, Vol. 23, No. 5, 2011, pp. 571-591.

Porto, N.; Rucci, A.; Darcy, S.; Noebilia, G.; Almond, B. Critical elements in accessible tourism for destination competitiveness and comparison: Principal component analysis from Oceania and South America. Tourism Management, Vol. 75, 2020, pp. 169-185. 
Raya, M.; Ryderb, M. Ebilities' tourism: an exploratory discussion of the travel needs and motivations of the mobility-disabled. Tourism Management, Vol. 24, No. 1, 2003, pp. 57-72.

Republic of Cyprus. Hotel regulations 18985-2014. Retrieved from http://www.tourism.gov.cy/tourism/tourism.nsf/All/60CE56C11DAA04D5C22584B100 31BD55/\$file/Oi peri Xenodoxeion kai Touristikon Katalymaton Organomena Dia merismata kai Touristika Xoria Kanonismoi 1993 eos 2014 enop.pdf?OpenElem ent [accessed 12 June 2020].

Scope 2021. The social model of disability. Retrieved from http://www.scope.org.uk/about-us/our-brand/social-model-of-disability [accessed 25 November 2021].

Scott, R. Accessibility is not inclusion. 2011. Retrieved from https://www.academia.edu/3619225/Accessibility is NOT Inclusion [accessed 25 November 2021].

Shakespeare, T.; Watson, N. The Social Model of Disability: an outmoded ideology'. Research in Social Science and Disability, Vol. 2, 2002, pp. 9-28.

Shaw, G.; Coles, T. Disability, holiday making and the tourism industry in the UK: a preliminary survey. Tourism Management, Vol. 25, No. 3, 2004, pp. 397-403.

Smith, M.L.; Amorim, É.; Umbelino, J. Accessible Tourism and Disability Service Information Provided on Leading Airline Websites: A Content Analysis. International Journal for Responsible Tourism, Vol. 2, No. 4, 2013, pp. 7-23.

SOCYTEC. Manual de Accesibilidad Universal para Hoteles. 2007. Retrieved from https://www.librosarq.com/manual/manual-de-accesibilidad-universal-parahoteles/\#.YTcMOo4zZPZ [accessed 6 September 2021]. 
Storey, J. Human Resource Management. A Critical Text. London, New York: Routledge, 1995.

Swansson R.A. Evaluation, a state of mind. Advances in Developing Human Resources, Vol. 7, No. 1, 2005, pp. 16-21.

Tantawy, A.; Kim, W.; Pyo, S. Evaluation of Hotels to Accommodate Disabled Visitors. Journal of Quality Assurance in Hospitality \& Tourism, Vol. 5, No. 1, 2005, pp. 91-101.

Tatic, D. Access for People with Disabilities to Culture, Tourism, Sports and Leisure Activities: Towards Meaningful and Enriching Participation. 2015. Retrieved from https://www.coe.int/en/web/disability [accessed 25 November 2021].

Tchetchik, A.; Eichhorn, V.; Biran, A. 'Not on my vacation': service encounters between able-bodied and disabled consumers-the case of high-contact service. Journal of Policy Research in Tourism, Leisure and Events, Vol. 10, No. 9, 2018, pp. 1-17.

UN - United Nations. Convention on the Rights of Persons with Disabilities (CRPWD), Article 1, Purpose. 2006.2 Retrieved from https://treaties.un.org/doc/Publication/CTC/Ch IV 15.pdf [accessed 25 November 2021].

UNWTO - United Nations World Tourism Organisation. UNWTO, ONCE Foundation and PREDIF join forces to promote Accessible Tourism at FITUR 2015. Retrieved from https://www.unwto.org/archive/global/press-release/2015-02-03/unwto-oncefoundation-and-predif-join-forces-promote-accessible-tourism-fit $\quad$ [accessed 25 November 2021].

UNWTO - United Nations World Tourism Organisation. Disability. Retrieved from https://www.unwto.org/accessibility [accessed 18 June 2019]. 
Var, T.; Yeşiltaş, M.; Yayli, A.; Öztürk, Y. A Study on the Travel Patterns of Physically Disabled People. Asia Pacific Journal of Tourism Research, Vol. 16, No. 6, 2011, pp. 599-618.

Vila, T.; Darcy, S.; González, E. Competing for the disability tourism market - A comparative exploration of the factors of accessible tourism competitiveness in Spain and Australia. Tourism Management, Vol. 47, No. 1, 2015, pp. 261-272.

Wang, G.; Wilcox, D. Training evaluation: knowing more than is practiced. Advances in Developing Human Resources, Vol. 8, No. 4, 2006, pp. 528-539.

WHO - World Health Organization. 2019. Disability. Retrieved from https://www.who.int/topics/disabilities/en/ [accessed 20 June 2019].

WTTC - World Travel and Tourism Council. Economic Impact 2020. Retrieved from https://wttc.org/Research/Economic-Impact [accessed 29 June 2020].

Yang, C.; Guo, N.; Wang, Y.; Li, C. The effects of mentoring on hotel staff turnover. Organizational and occupational embeddedness as mediators. International Journal of Contemporary Hospitality Management, Vol. 31, No. 10, 2019, pp.4086-4104.

Yau, K.; McKercher, B.; Packer, T. Traveling with a disability. More than an access issue. Annals of Tourism Research, Vol. 31, No. 4, 2004, pp. 946-960.

Zhang, H.; Wu, E. Human resources issues facing the hotel and travel industry in China. International Journal of Contemporary Hospitality Management, Vol. 16, No. 7, 2004, pp. 424-428.

Article info: Received 10/08/2021. Accepted 26/11/2021. Refereed anonymously. 